FOLIA SCANDINAVICA VOL. 24 POZNAŃ 2018 DOI: $10.2478 / \mathrm{fsp}-2018-0007$

\title{
Å REISE NORDOVER ELLER $\AA$ UTFORDRE DET NORSKE: AILO GAUPS TROMMEREISEN OG HELENE URIS RYDDE UT
}

\author{
MARIA SIBIŃSKA \\ University of Gdańsk
}

ABSTRACT. The article elucidates the presence of the Sami undercurrent in Norwegian literature. Proceeding from Elisabeth Oxfeldt's theoretical work on the post-national and on the Bhabhanian concept third space, two novels are being discussed: Ailo Gaup's Trommereisen (1988) and Helene Uri's Rydde ut (2013). Gaup's works constitute the first samic voice in Norwegian literature, which explicitly verbalizes the despair emanating from the loss of continuity as regards to the self-image and the self-identity of many samic individuals. Uri's auto-fictional text combines family research with editing and correcting the nation's biography. Emphasizing the novels employment of the travel north as a driving force behind the plot and as a metaphorical device, the author of the article interprets the novels as an expression of hope to transgress the social reality and re-establish the lost coherence of personal and national history either by means of shamanic knowledge and practice (Trommereisen) or by means of discursive practice (Rydde $u t$ ) that liberates the individual from rigid preconceptions regarding identity and cultural belonging.

\section{IDENTITETENE SETTES PÅ SPILL \\ 1.1 DEN SAMISKE UNDERSTRØMMEN}

Bildet av en nasjon som noe homogent, er utopisk, og det flerkulturelle Skandinavia er ikke et resultat av de siste tiårenes innvandringspolitikk: "The Nordic Countries, northern Scandinavia in particular, have been populated by Swedes and Norwegians since a thousand years, but the countries have also hosted refugee children from Finland, traveling 
salesmen from Germany, immigrant Wallonian workers, traveling Roma and rejected Saami forcefully converted to Christianity" (Jonsson, 2017). Den norske etnografen og kulturfilosofen Jens Ivar Nergård hevdet på 1990-tallet at hele den nordnorske befolkningen egentlig skulle ha en eksistensiell interesse i å synliggjøre det samiske elementet $\mathrm{i}$ det nordnorske kulturlandskapet (Nergård, 1994). I 2010-årene framstår en slik problemstilling som uaktuell. "Drøye 100 år etter at norske myndigheter satte i gang systematisk fornorskning av den samiske befolkningen, kommer de siste ettervirkningene til overflaten. Etter tiår med hemmelighold, fornektelse og skam blir familiehemmelighetene avslørt, en etter en", skrev Aftenposten i 2009, i forbindelse med lanseringen av dokumentarfilmen Min mors hemmelighet ${ }^{1}$. Det har etter hvert blitt klart at den samiske understrømmen ikke er geografisk stedfestet til områdene nord for polarsirkelen. For det første førte både de langvarige assimilerings- og fornorskningsprosessene og den generelle nedrakkingen av samene til at mange samiske familier fram til andre verdenskrig valgte bort samisk språk framfor norsk $\mathrm{i}$ håp om at deres barn skulle slippe vonde opplevelser. "Da disse barna igjen fikk barn, vokste de opp som norske. Det ble ikke snakket om bakgrunnens deres, og at besteforeldrene var samer. (...) I enkelte kyst- og fjordstrøk ble på denne måten røttene til det samiske kutta over i løpet av to generasjoner" (Drivenes et al., 1994: 259). I tillegg satte andre verdenskrig og tvangsevakueringen av Finnmark og Nord-Troms preg på den nordnorske befolkningens spenningsfylte, til dels betente, slektshistorier. En del av nordlendingene som hadde blitt drevet på flukt, valgte å bli sørpå etter krigen, og "i storbyen gjaldt det å snakke bokmål og gå i høyhælte sko" (Østtveit, 2009). Et ukjent antall av dem hadde hatt samiske aner som de enten ville skjule, eller som de ikke var klar over. Med andre ord bør Nergårds påstand omskrives: Hele den norske befolkningen har en eksistensiell interesse $i$ å synliggjøre det samiske elementet i det norske kulturlandskapet.

\subsection{DEN POSTNASJONALE DISKURSEN}

Sett identitetene og/eller individenes og gruppenes språk på spill, og analyser hver homogen diskurs, umulig sosial gruppering eller institusjon, oppfordret Julia Kristeva i sitt kjente essay "Dissidenten - en ny type intellektuell" (Kristeva, 1995: 66). Hennes oppfordring har fortsatt ikke mistet sin

\footnotetext{
${ }^{1}$ Filmens regissør og sentrale fortellerstemme, Ellen-Astri Lundby fra Oslo, fikk aldri høre noe om sin mors samiske røtter da hun vokste opp. Det ble bare sagt at mora var fra Nord-Norge og at hun - som mange andre - flyttet sørover etter krigen. "Den ene gangen Ellen selv spurte om familien hadde noen sametilknytning, ble moren likevel så uforklarlig sint. Først i dag forstår Ellen at det ikke var sinne. Det var redsel. "Hun må ha brukt utrolig mye energi på å skjule at hun var samisk." Lundbys prosjekt, som er å kartlegge sin mors og sin egen fortrengte slektshistorie, drives av filmskaperens reise nordover (Østtveit, 2009).
} 
aktualitet i dagens samfunns- og kulturdebatt, ikke minst i forbindelse med postnasjonale prosjekter som setter spørsmålstegn ved homogenitetstenkning om nasjoner og om nasjonale og etniske identiteter. I nyere norsk litteratur er synliggjøring av det samiske blitt en del av den postnasjonale diskursen, slik den defineres av Elisabeth Oxfeldt. I boka Romanen, nasjonen og verden. Nordisk litteratur $i$ et postnasjonalt perspektiv tar hun utgangspunkt $\mathrm{i}$ begrepet "den nasjonale roman". Den nasjonale romanen, som blomstret opp i løpet av 1800-tallet i kjølvannet av nasjons- og identitetsskapende prosjekter i de vestlige samfunnene, oppfatter hun som en metonymisk, allegorisk, nasjonspedagogisk fortelling, der enkeltindividets skjebne fremstilles med Historien i bakgrunnen. Med forankring i bl.a. den postkoloniale teoretiseringen til Homi Bhaba, betraktet hun den postnasjonale diskursen, som har gjort seg gjeldende etter andre verdenskrig, heller som en utvidelse og bearbeidelse enn forkastelse av nasjonsbegrepet.

Litteratur som oppfordrer til en redefinering av nasjonsbegrepet, deler Oxfeldt i fire tematiske undersjangere: nasjonskorrigerende fortellinger, filosofisk dekonstruerende fortellinger, skyld- og skamfortellinger og minoritetens motfortellinger. De overlapper hverandre, og felles for dem er problematiseringen av det essensialistiske bildet av nasjonen. I den første gruppen plasserer Oxfeldt nasjonskorrigerende eller "refsende" fortellinger som retter søkelyset mot den ferdigbygde nasjonen som har havnet på feil spor, særlig med tanke på dens internasjonale rolle. Selv om Oxfeldt ikke legger vekt på det, kan man i denne undersjangeren også plassere fortellinger som retter den kritiske brodden mot nasjonens interne forhold. Den filosofisk dekonstruerende romanen stiller seg derimot kritisk til den positivistiske tid- og historieoppfatningen, og dermed polemiserer den med selve ideen om en nasjonal historie. De to gjenstående undersjangrene tematiserer møter mellom minoritetsog majoritetskulturer. Den ene identifiserer Oxfeldt som skyld- og skamfortellinger om urbefolkningen. Her gransker man den urettferdige behandlingen av urfolket, som gjerne fant sted i de unge nasjonalstatene - ikke minst i Norge. Den andre undersjangeren, som også springer ut fra møter mellom storsamfunnet og minoriteten, omfatter motfortellinger, der perspektivet bestemmes og ordet føres av representanter for befolkningsgrupper som føler seg ekskludert fra den nasjonale diskursen og dens definering av "vi, folket".

Foreliggende artikkel er et forsøk på å kaste lys over den samiske understrømmens nærvær i det norske litteraturlandskapet. Med utgangspunkt i Elisabeth Oxfeldts teoretisering rundt det postnasjonale, skal det presenteres to romaner: Ailo Gaups Trommereisen (1988) og Helene Uris Rydde ut (2013). Etter artikkelforfatterens kjenskap har det blitt lite fokusert på disse to 
romanene med hensyn til samisk identitetsproblematikk ${ }^{2}$. Bruker vi Oxfelds kategori, kan Gaups litterære prosjekt identifiseres som en motfortelling. Hans forfatterskap tilhører den første bølgen av den samiske kulturrevitaliseringen, som oppstod i kjølvannet av Alta-saken ${ }^{3}$. Trommereisen viderefører metaforikken og motivkretsene som Gaup introduserer i sin poesi allerede i 1982, og hans diktning er den første samiske stemmen innen den norskspråklige litteraturen, som eksplisitt verbaliserer fortvilelsen over den tapte kontinuiteten i selvforståelsen hos mange av de norske samene.

Trommereisen og den autofiktive Rydde ut, som på sett og vis kan sorteres under "skyld- og skam"-kategorien, har en tidsavstand på 25 år. De har likevel et vesentlig tematisk fellespunkt som gjør det meningsfylt å sammenstille dem: De bruker en reise nordover som et handlingsdrivende og metaforiserende element.

\section{TROMMEREISEN}

\section{1 “JEG ER FØDT PÅ RØYEHODET, / ET FJELL I RIMFROSTMANNENS RIKE”}

Reisen nordover, som skal bringe det skrivende jeg nærmere sannheten om seg selv, og som skal gi henne/ham ny innsikt i menneskets og verdens natur, er et veletablert topoi i litteraturen. I norsk-samisk sammenheng ble det tydelig verbalisert på 1980-tallet, takket være Gaups forfatterskap. I hans prosa- og poesitekster danner den konkrete geografiske reisen nordover en parallell til subjektets søken både etter det tapte hjemmet og det fortrengte samiske i hans "jeg".

Gaup ble født i nærheten av Kautokeino i Finnmark. Som syvåring ble han adoptert bort, og han vokste opp hos en norsk adoptivfamilie i Larvik. Først som voksen fikk han anledning til å finne tilbake til den familiære og kulturelle sammenhengen han ble fravristet som barn. Som Oslo-journalist fikk han et oppdrag for Aftenposten i 1972, og dro til Kautokeino for å lage en reportasjeserie om samenes liv. Reisen ble et gjennombrudd for ham: Blant annet fikk han møte sin mor for første gang på 21 år:

2 Trommereisen er så vidt nevnt i Sibińska 2002, der man diskuterer etnisiteten i jegpersonens selvoppfattelse i Gaups poesi. I Sibińska 2000 står formidling av det sjamanistiske i sentrum, og identitetsproblematikken har en sekundær betydning. Ellers nevnes fortellerens og forfatterens samiske identitet i korte omtalelser av romanen (f.eks. Rottem 1990). Den etniske dimensjonen ved identitetsproblematikken $\mathrm{i}$ Uris roman påpekes $\mathrm{i}$ forbindelse med bokas presseomtaler (f.eks. Lerum 2013), men det er likevel ikke snakk om noen dyptgående analyser.

${ }^{3}$ Alta-saken kalles en konflikt om vannkraftutbygging i Finnmark som pågikk i årene 1968 til 1982, med kulminasjon i 1981 med samiske sultestreiker i Oslo. Saken ble til en impuls for kulturell og polistisk oppvåking av samene og fikk stor betydning for utviklingen av norsk samepolitikk. 
Jeg er født på Røyehodet,

et fjell i Rimfrostmannens rike.

Da mine forfedre kom var landet

tomt. Det bærer jeg med meg,

liker å treffe stammefrender,

kjenne strålene varme (...)

Dette var hans opprinnelsesmyte. Han påkalte stammenes krefter, kreftene i det innvendig befolkede fjellet og Gud Sol (Gaup, 1988: 179).

Det er vanskelig å se bort fra det dramatiske ved hans oppvekst når man nærmer seg hans litterære prosjekt, der søken etter identitet og tilhørighet står sentralt, og sjamanisme og gjenforening med den mytiske kunnskapen framstår som strategien for å gjenvinne sin indre og ytre sammenheng. Et slikt formulert prosjekt strukturerer både Gaups poesi (Joiken og kniven, 1982; I Stallos natt, 1984, Under dobbel stjernehimmel, 1986) og hans romaner (Trommereisen, 1988; Natt mellom dagene 1992), som alle er blitt forfattet på norsk siden hans ferdigheter i samisk ikke var tilstrekkelige. Gaups transkulturelle bakgrunn samt den personlig opplevde fornorskingsprosessen gjør hans biografi til et eksempel på de norske samenes skjebne. Samtidig blir det moderne menneskets hjemløshet, tap av tilhørighet og identitetskriser konkretisert i lys av hans biografi (Sibińska, 2000, Sibińska, 2002).

\subsection{DET NORDLIGE LANDSKAPET ELLER Å VÆRE MELLOM VERDENENE}

Tittelen Trommereisen konnoterer minst to betydninger i Gaups roman. Den viser til den imaginære reisen som foregår i transen, på trommelyden. Samtidig henviser den til den konkrete reisen som foretas av romanens hovedperson, Jon. Han er en journalist av samisk opphav, som har vokst opp sørpå hos en norsk adoptivfamilie og dermed mistet en del av sitt "jeg”. Når romanen begynner, er han og hans samboer, Lajla, på vei fra Oslo til Finnmark, til det som en gang i fortiden var hans hjemtrakter. På det realistiske planet dreier fortellingen seg stort sett om relasjonene mellom Jon og Lajla, om spenningen mellom dem og Lajlas samisk-finske familie, som de besøker under sitt opphold i Finnmark. Særlig anspent er begges forhold til Tomas, Lajlas tyranniske, finske far. Tomas' bastante avvisning av den førkristne samiske kulturen gjør at han kommer på kollisjonskurs med Jon, og hans perfeksjonisme har Lajla slitt med gjennom hele sin oppvekst.

Dessuten får vi - gjennom skildringer av møtet med venneparet Liisa og Heaika - korte, fragmenterte bilder av Jons fortid som politisk aktivist. "Alt er blitt brødpolitikk og bekvemhet. Det var annerledes den tida da vi kjørte jorda rundt på Nordkalotten, Jon, for egen regning og møttes i gammer og lavvoer og planla" (Gaup, 1988: 132). Disse bildene antyder, gjennom å koble det 
politiske arbeidet til den tradisjonelle levemåten (lavvoer og gammer), fortellerens essensialistiske holdning til det samiske.

Når reisen nordover begynner, har Jon en fornemmelse av at "noe kommer til å skje, noe farlig, og nå var det i gang” (Gaup, 1988: 8). Det er med andre ord et varsel om noe nærmest freudiansk uhyggelig og marginalisert som vil åpenbare seg for de involverte. Ekspedisjonen arrangeres fordi Jon opplever en serie sterke og konkrete drømmer: En samisk sjamantromme har kommet $\mathrm{i}$ fremmede hender som vil bruke den til å utøve ondskap. Hans oppgave blir dermed å føre trommen og de kunnskapene trommen vokter over, tilbake til samefolket. Selv om fienden klarer å ødelegge trommen fysisk i slutten av romanen, går kraften som trommen har voktet over, ikke tapt, men blir til en del av Jons "jeg".

Hovedpersonens reise til de nordlige landskapene blir etter hvert til et møte med urmyter, og den resulterer i hans innvielse i sjamanistiske ritualer. Den sjamanistiske veien er for Jon en videreføring av den politiske oppvåkningen: 'Den gangen fungerte det politiske språket. Innover og utover. Da var ordene nøkler. Det låste opp dører til større forståelse. Nå trenger vi nye ord som kan låse opp til den nye forståelsen som trengs" (Gaup, 1988: 133).

Med andre ord bestemmer hovedpersonen seg for å utforske de virkelighetsdimensjonene som mange av samene, innlemmet i den kristelige forestillingsverden, ikke vil vedkjenne seg. "Jeg jobber med den mest undertrykte delen av vår identitet. På det området er det også vi selv som undertrykker oss selv. Vi har kastet vrak på forfedrenes åndelige arv. Et folk uten fortid er et folk uten framtid", sier Jon til sin venn, Heaika og tilføyer: "Det jeg leter etter, er den kunnskapen som kan helbrede kroppene og sjelene (...) Vi er det eneste folk i Europa som har en slik arv i live" (Gaup, 1988: 131).

Helt fra første stund preges hovedpersonens møte med hjemtraktene ikke bare av noe uhyggelig, men også av noe overskridende. Gjennom det gjenkjennelige 1980-tallets Finnmark skimtes mytiske, evige landskaper: "I det samme ble himmelen klar igjen. Det var som å komme ut av en tunnel. Landskapet ble synlig rundt dem. Månen sto mellom fjellene. Lyset var gult. Da så Jon noe merkelig. Ei sol skinte ut i natta fra ei fjellside (Gaup, 1988: 17).

Fortellingen i Trommereisen framstår på sett og vis som en palimpsest, med en poetisk understemme som er med på å formidle Jons møte med det mytiske. Erindringene som dreier seg om møter med virkelighetens mytiske dimensjon, skimtes gjennom prosalaget. En slik framstillingsmåte, hvor den prosaiske overflaten undermineres av poetisk-mytiske utbrudd, gjenspeiler Jons møte med det nordlige landskapet som utspiller seg på to plan - den konkrete Finnmarkskvidda og drømmeverdenen: 
Da fikk Jon øye på to blåklokker ytterst ute på skrenten. Han var virkelig mellom verdenene. For dette var forfedrenes blomster. Han så og hørte dem klart, samtidig som han kjente lukta av jord og vann og kjente bakken under seg (...)

Jeg vil natt.

Jeg vil jord.

Jeg vil de innerste drømmebildene.

Det er et liv av minner.

Når jeg forsøker å huske,

glemmer jeg.

Uro er å påkalle

noe uønsket (Gaup, 1988: 181-182)

En av sjamanens viktigste oppgaver var å fortelle om sine trommereiser til sitt folk, og fortolke transeopplevelsene. Sjamanen skulle etablere kontakt mellom menneskene og åndenes verden, og skulle fungere som en veiviser i de mytiske landskapene. Som oftest hadde meddeling av den type erfaringer tatt form av muntlige meddelelser til de innvidde. Gaups forteller tar på seg sjamanens rolle ved å inkorporere hovedpersonens sjamanistiske transeerfaringer i den norske litterære diskursen. Siden fortellingen (ned-)skrives på norsk, dreier hans misjon seg ikke bare om det samiske folk.

\subsection{DET EKSILERTE SUBJEKTET? DET MIGRERENDE SUBJEKTET?}

Migranten har blitt det siste århundrets hovedaktør, og migrasjonsprosessene har resultert i redefineringsprosesser av hjem- og identitetsoppfatning, hevder Søren Frank (Frank, 2008). Selv om dette kan oppfattes som en generalisering, kan man ikke se bort fra det faktum at "migrasjonsbevegelsene, eksilet og et mangfold av kulturmøter framstår som bredt representerte følger av globaliseringer i nyere litteratur" (Andersen 2013: 47).

Allerede i romanens åpningssekvens finnes det en tydelig parallell mellom det konkrete landskapet og det imaginære, utopiske, ikke-eksisterende, tapte hjemmet som ikke lar seg vinne tilbake gjennom et nostalgisk hjemreiseprosjekt; eller som Bhabha uttrykker det: "the recurrent metaphor of landscape as the inscape" (Bhabha, 1999: 295). Hos Bhaba er det ytre landskapet ekvivalent til den nasjonale identitetens indre landskap. Hos Gaup dreier de indre landskapene seg heller om individets og (minoritet-)folkets integritet. Det geografiske landskapet blir ikke bare til hjemmet, det blir til den moren Jon mistet som barn:

Men etter hvert som nattsynet våknet, dukket fjellene og vidda ut av mørket under en måne i ne, en langsom fremkalling av et landskap, og en fantasi. (...) Vidda var vid og åpen rundt dem. De nakne, kvinnelige formene nådde ham plutselig, nådde 
inn i kjertlene, driftene og drømmene hans. Et kvinnelig landskapslegeme snakket til ham fra silhuett bak silhuett. De avrundede bakkene og spissede fjellene var som hofter og bryster rundt ham. Han har kommet hjem" (Gaup, 1988: 6).

Den nordlige naturens kvinnelige trekk forsterkes ved at Jons møte med den blir erotisert, og teksten bygger en klar parallell mellom mannens møte med hjemmelandskapet og elskov med kvinnen i hans liv.

Igjen skapte berøringen et sug i ham, som rommet hele deres forhold av ømhet fra første gang til nå (...) Hun skvatt til, lo og så omfavnet hun ham, holdt ham hardt inntil seg. Omfavnelsen var annerledes her, følelsen mer pirrende. Lajlas intensitet, kvinnelandskapet rundt ham og det å ha nådd hjem gav ham en egen, sitrende følelse (Gaup, 1988: 7).

Jon drives av et sterkt ønske om å kunne vende hjem, selv om hjemmet ikke betraktes som noe konkret. Dette gjør ham til et individ i eksil ${ }^{4}$. Mens Kristeva romantiserer eksiltilværelsen ("Vår epok är exilens epok. Enda sättet att rädde sig från att sjunka ned i sunda förnuftet är att gå i exil från sitt land, sitt språk, sitt kön, sin identitet. Att skriva är umulig utan någon form av exil', Kristeva, 1995:70), er Edward W. Said mye mer ambivalent i sitt syn på dette fenomenet. Han slår fast at å betrakte en eksiltilværelse bare som noe fordelaktig, bare som en stimulerende faktor innen kultur eller kunst, er å bagatellisere eksilets ødeleggende virkning: "Modern exile is irrimediably secular and unbearably historical. It is produced by human beings for other human beings; it has torn millions of people from the nourishment of tradition, family, and geography" (Said, 1984: 50). I sin betraktning av motsetningsparet hjemmet/eksilet verdsetter han likevel eksilsituasjonen. For Said innebærer eksil grensekryssing, ikke bare i geografisk betydning, men også en utfordring for tankeog erfaringsbarrierer. De fleste mennesker, skriver han, kjenner til én kultur. Det eksilerte mennesket kjenner minst til to, og denne pluraliteten er utgangspunktet for noe Said kaller kontrapunktisk bevissthet: "For an exile, habits of life, expression, or activity in the new environment inevitably occur against the memory of these things in another environment. Thus both the new and the old environments are vivid, actual, occurring together contrapunctally" (Said, 1984: 55). Saids kontrapunktiske bevissthet resulterer i en overskridelse av den tradisjonelle opposisjonen vi/de; den innebærer ikke så mye subjektets

\footnotetext{
${ }^{4}$ Skillet mellom eksil og migrasjon kan likevel bli flytende: Mens eksil oppfattes som en tvungen tilstand av å måtte holde seg borte fra eget land eller hjemsted, betyr migrasjon en frivillig eller ufrivillig forflytning av folkegrupper eller individer. Grensen mellom eksil og ufrivillig migrasjon er ikke alltid tydelig (Andersen, 2013: 47).
} 
veksling mellom "sentrum"- og "periferi"-perspektivet, men heller en simultan posisjonering: både i senteret og i periferien.

Jons eksiltilværelse er kilden til savn, men også til unike egenskaper. Hans prosjekt dreier seg likevel om å komme seg ut av eksiltilværelsen og om å overvinne de ødeleggende vi-de-motsetningene ved hjelp av den nyervervede kunnskapen. En av romanens siste sekvenser skildrer Jon, som på sjamanistisk vis opplever "kroppens omkonstruering" (Szyjewski, 2005: 6), noe som gir ham nye krefter:

Da lunte bjørnen fram på sine myke labber. Brått fór den på ham, lemlestet ham og var vekk. Langsomt kom han til seg selv. Bit på bit av kroppen hans føyde seg sammen på nytt, til en ny kropp, en ny helhet. Det kjentes som å bli født på nytt, men mer hel enn noensinne. Han forsto at ingenting var ødelagt. Alt var sammenhenger. Det hadde bare vært usynlig før. Nå kom årsakene til syne, akkurat som de drømmene som hadde vært årsaken til denne reisen. Det var som om han hadde opplevd alt før. Han måtte bare gjenoppdage det (Gaup, 1988: 215).

Jons helhetsfølelse som i romanen knyttes til de mulighetene som ligger i sjamanismens urkrefter, får en tilleggsforankring i hans slektshistorie. Den brutte slektslinjen rekonstrueres, for Jon oppdager bånd som knytter ham til den forrige rettmessige eieren av sjamantrommen: Vedkommende var hans biologiske far.

Jons helhetsfølelse er ekvivalent med å endelig komme hjem igjen. I Fictions of (In)Betweenness (1997) trekker Claudia Egerer paralleller mellom opposisjonene senter/periferi og hjem/eksil. Det å være i sentrum betyr for henne en parallell følelse til "det å være hjemme", siden begge posisjonene konstituerer jeg-ets tilhørighetsfølelse. Den som befinner seg hjemme / i sentrum kan lett forestille seg at han/hun har kontroll over sin tilværelse. Tap av hjemmet blir til en viss grad opplevd som fortrenging fra sentrum mot periferien. Jons reise nordover/hjemover kan dermed oppfattes som en metafor på en bestrebelse etter å gjenvinne bestemmelsesposisjonen, noe han lykkes med. Jons eksiltilværelse er over, og det utopiske prosjektet er fullført. Omkonstrueringen av Jons kropp, sjel og bevissthet skal føre til gjenopprettelse av den tapte kontinuiteten i individets selvbilde, i dets historiske, kulturelle og familiære kontekst. Selv om man stadig blir gjort oppmerksom på at "Odysseus's homecoming (a return to and of the same order) no longer seems possible in our contemporary world of rapid transformations" (Frank, 2008: 1), er behovet for imaginære hjemkomster fortsatt iboende i det moderne mennesket, noe Trommereisen er et litterært uttrykk for. 


\section{RYDDE UT}

\subsection{EN SØKEN ETTER SAMMENHENG ELLER OM Å PENDLE MELLOM SJANGRE}

Helene Uri (f. 1964) er forfatter og språkforsker med doktorgrad i lingvistikk og med en akademisk karriere bak seg. Hun debuterte i 1995, og siden da har hun regelmessig publisert litteratur i forskjellige sjangre. Hun har skrevet både fagbøker, romaner og barnebøker. Rydde ut, hennes bok nr. $21 \mathrm{og}$ roman nr. 7, er en sjangermessig hybrid. Dens handling utspiller seg på to fiktive nivår som flettes inn i hverandre, og leseren tvinges til å stadig skifte perspektiv.

På det primære nivået har vi med autofiktiv prosa å gjøre, med fiksjonalisering av slektsgranskning. Den autofiktive jeg-stemmen bestemmes av den dobbelte utsagnsposisjonen: Det talende jeg virkelighetsforankres (navnet hennes er identisk med forfatteren bak Rydde $u t$ ), men samtidig er stemmen en del av en tekst hvis sjanger beskrives på tittelsiden som roman.

Jeg-fortelleren er en kjent forfatter, Helene Uri, som arbeider med en roman om Ellinor Smidt, en småfrustrert lingvist fra Oslo. Mens skriveprosessen er i startfasen, blir Helene oppringt av en ukjent kvinne som presenterer seg som hennes slektning fra Nord-Norge. Denne telefonsamtalen setter handlingen riktig i gang. Uri vet ikke mye om sin nordnorske farfar Nicolai Nilsen, som ble født på Sørøya ved Hammerfest og var overingeniør på Notodden da han døde i 1937, bare 42 år gammel. Da Helene gjør et søk på Nicolai, oppdager hun at hun kommer fra sjøsameslekt.

Der i folketellingen fra 1910, fra Hammerfest herred. Farfar, født i 1896. I 1910 er ikke Nicolai hjemme i Bismervik på Sørøya. Tilholdssted ukjent, trolig Alten. Etter farens navn, Ole Nilssen, står det to bokstaver: If. Kona hans er n. Bak alle barna står bokstaven $\mathrm{b}$. I innledningen til registeret gjenfinner jeg kodene; $\mathrm{b}$ står for blandet, $\mathrm{n}$ står for norsk, If står for lappisk fastboende. Min oldefar var same. Same. Det har ingen fortalt meg (Uri, 2013: 24).

Helenes rekonstrueringsprosess tar utgangspunkt i noen få opplysninger og et enkelt fotografi. Ved hjelp av arkivsøk og utspørringer blant den omsider kartlagte slekten, klarer hun å føye til noen elementer (blant annet informasjon om søskenflokken til farfaren, hans skolegang i Alta, ingeniørutdannelsen i Trondheim, et utenomekteskapelig barn som ble unnfanget mens Nicolai studerte i Trondheim og som han tydeligvis ikke ville vedkjenne seg). Men det er først og fremst Helenes forestillingsevner som skaper en sammenhengende diskurs av disse små partiklene.

Mens Helene er i ferd med å oppdage sin families fortid, dør hennes mor. Morens død setter i gang en erindringsprosess som hjelper Helene med å legge merke til sammenhenger og mønstre som hun tidligere ikke har sett. Hun bearbeider sorgen gjennom opprydning i sin mors etterlatte eiendeler, noe som 
skjer parallelt med hennes forsøk på å rekonstruere slektens skyggelagte historie.

Den selvframstillende jeg-fortellingen settes i relieff av det sekundære fiksjonsnivået, en roman-i-roman, som utgjøres av jeg-personens bokprosjekt. Det sekundære nivået fylles med en tredje persons fortelling som etterhvert preges av overtydelige populærlitterære trekk og som utvikler seg parallelt med Helenes søken etter den tapte sammenhengen i sin egen livshistorie. Hovedpersonen i Helenes roman er Ellinor Smidt, som har doktorgrad i lingvistikk, men som er uten noen spennende jobbutsikter. Hun får stilling på et prosjekt om språkdød som går ut på dokumentering av de kulturhistoriske og samfunnsmessige rammene rundt de truede samiske språkene i Finnmark. Oppdraget blir for henne en form for flukt fra et utbrent forhold og et lite tilfredsstillende arbeid. Reisen nordover - og den geografiske avstanden til Oslo - er i tillegg en forberedelse til den endelige avskjeden med faren, som nå er innlagt på institusjon. Han lider av Alzheimers sykdom og glir gradvis vekk fra språket og virkeligheten. Fylt med klisjeer om landets nordlige fylke, uten noen særlige forkunnskaper om den samiske kulturen og uten å kunne språket/språkene hun skal dokumentere, drar Ellinor til Finnmark. ("Det skal uansett bli godt å komme seg ut herfra, fra denne leiligheten, hennes og Toms. Sápmi - here I come! Finnmark er mulighetens land", Uri, 2013: 33).

Disse to fortellingstrådene utvikler seg parallelt i Rydde ut, og har flere berøringspunkter: "Vi sitter rygg mot rygg, lener oss mot hverandre. Ellinor ser framover. Jeg ser bakover. En gang imellom vrir vi hodet og kikker oss over skulderen, så jeg ser fremtiden og hun fortiden" (Uri, 2013: 92). Mye av fortellingen på begge fiksjonsnivåene dreier seg om bearbeidelse av tap og sorg. Tapet tematiseres gjennom flere motiviske linjer. I narrasjonens nåtid opplever begge kvinnene - både Helene og hennes fiktive Ellinor - nære personers død. Helene mister sin mor, og Ellinor sin far. Romanens tittel henviser blant annet til den konkrete opprydningsprosessen etter den avdøde, som samtidig blir en erindringsprosess. Tittelen har også destruktive konnotasjoner - den kan assosieres med utrydning og utslettelse av både kulturer og mennesker.

Helenes fortelling skaper et flerdimensjonalt rom for sorgprosessen: Den etablerer ekvivalensen mellom bearbeidelsen av morens død og konfrontasjonen med den ukjente farfarens liv. Hun får tårer i øynene av tanken på den nylige avdøde moren, men hun reagerer også med tilsynelatende ubegrunnet, ukontrollert gråt på sitt første møte med den skjulte fortiden: "Tårene renner og renner og jeg skjønner ikke hvorfor" (Uri, 2013: 26). Et annet sted møter vi Helenes melankolske tilståelse:

Min far som foretrakk Van Heusen-skjorter, gikk med slips om vinteren og rituelt skiftet til tversoversløyfe på vårparten, hadde en far som muligens var vokst opp i 
en jordgamme, en primitiv hytte, uten vinduer, med åpent ildsted og ljore i taket. Bak øynene mine svir det i tårer som vil ut. Er jeg rørt? Kanskje, men mest av alt trist fordi jeg aldri spurte nok." (Uri, 2013: 42)

Romanen legger vekt på gjenstandenes funksjon: Minnene om de avdøde og deres slekt rekonstrueres gjennom tingene de har omgitt seg med: "Tingene er bindeledd til fortiden, bindeledd man kan se, berøre, lukte på", sier Helene og minnes sine samtaler med den avdøde moren: "Det var mange temaer vi aldri berørte. Det er temaer som er forbeholdt venninner, temaer som er forbeholdt ektemenn. Men møbler, bestikk, malerier og fotografier var lett å snakke om. Ikke de som bare forsvant, som etterlot seg lyse flekker på teppet, tomrom i huset. Det snakket man ikke om" (Uri, 2013: 130).

I fortellingen gjenspeiles det individuelle i det kollektive. Sykdommen og alderdommen tærer på språkevnene til Ellinors far. Dette framstår som en parallell til det samiske folkets språktap, noe Ellinor holder på å dokumentere. Tapet av slektens kontinuitet på grunn av de etniske spenningene jeg-personen konfronteres med, er noe flere familier i Norge har blitt eller blir konfrontert med. I tillegg er Helene, som stilles overfor den fragmenterte kunnskapen om sin families fortid, like hjelpeløs som sin fiktive lingvist, som setter i gang forskning på de utrydningstruede språkene hun ikke skjønner. På den måten bygges det en ekvivalens mellom slektsgranskning og korrigering av nasjonens selvbiografi.

"Når en roman er ferdigskrevet, tilhører den ikke lenger forfatteren, men leserne. Når en person er død, er det de som er igjen, som overtar ham eller henne med sine minner og opplevelser eller med sine ønsker og omskrivninger", sier Helene og fremhever paralleller mellom sorgarbeidet og leserens møte med den litterære diskursen (Uri, 2013: 201). I begge prosesser dreier det seg om å etablere/reetablere forståelse, sammenheng og mening.

Kristeva beskriver i Svart sol, depresjon og melankoli en terapeutisk prosess som går ut på å knytte den melankolske personens affekter til de språklige tegn, slik at språket blir meningsbærende, og dermed egnet til å bearbeide tapet eller sorgen. En lignende prosess antydes i Rydde ut, og konkretiseres gjennom opprydningsbildet. De konkrete gjenstandene overtar en del av det verbale språkets funksjon, på tvers av den mangelfulle verbaliseringen. Man knytter betydninger til dem, de bærer meninger med seg og viser til affekter utover seg selv. Slektsgranskningsprosessen ville i den ideelle situasjonen kunne reetablere kontinuiteten i historien. Likevel viser det seg at å bringe de konkrete erfaringene, den tapte kunnskapen inn i Helenes slektshistorie - for å på den måten reetablere den ødelagte kontinuiteten - er en ambivalent oppgave. Jeg-fortelleren fyller "hullene" med metaforer, hun fyller dem med fiksjon, og fortellingen som skapes på denne måten, har en 
vilkårlig forbindelse til det reelle. Samtidig er fortellingen den eneste realiteten der reetablering av den tapte sammenhengen er mulig:

Min nesten grenseløse uvitenhet, mitt halvt ubevisste ønske om å forme fortiden så den passet meg, min pietetsfulle fantasi, min naivitet har gjort ham til en helt som kjempet for å få den utdannelsen han ønsket seg, som fant kjærligheten, som døde som offer for en sykdom yrket påførte ham. Sånn er historien blitt: Nicolai, den ambisiøse mannen fra nord, traff en ung kvinne, med samme utdannelse som han selv, men med en helt annen bakgrunn. De forelsket seg, min farfar og min farmor. Den sommeren de var forlovet, tviholdt han hånden hennes, kanskje børstet han kjærlig, men aldeles unødvendig, bort en smule fra kinnet hennes (Uri, 2013: 257).

\subsection{KJÆRLIGHETEN MED DET NORDLIGE I BAKGRUNNEN}

\section{ELLER EN FORTELLING OM SAMMENHENG}

Helene antyder at det å kutte bånd med det nordlige landskapet, også rent geografisk (faren tok aldri med sin kone dit), var for hennes far en form for fortrengning av egen herkomst. I rekonstrueringen av den fortrengte slekstshistorien betones først og fremst den mentale dimensjonen av reisen nordover. Likevel har dens konkrete dimensjon betydning for historiens narrative utforming og dermed videreføringen: "Jeg må dra til Hammerfest, Sørøya, Bismervik. Jeg må se det, høre historiene i luften" (Uri, 2013: 140).

Nord er "et sted som er lenger unna", og mens reisen sørover kan tolkes som en manifestering av det feminine, assosieres retningen nordover med det maskuline. Det finnes selvsagt en god del unntak fra denne regelen, og det nordlige kobles i flere sammenhenger med bilder av jomfruelighet eller farlig kvinnelighet. Det nordlige oppfattes av og til som et grenseland mot "den andre verden" (Schimanski et al., 2011: 12). Mens reiser sørover assosieres med noe avslappende og fornøyelig, knyttes reiser mot nord med prøvelser og utfordringer: "To say 'we leave for the north tonight' brings immediate thoughts of a harder place, a place of dearth: uplands, adverse weather, remoteness from cities. A voluntary northward journey implies a willingness to encounter intractable elements of climate, topography and humanity" (Davidson, 2005: 9). Dette er selvsagt generaliseringer formulert fra et bestemt perspektiv: Vestens, storsamfunnets. Sett fra det samiske innenfra-perspektivet kan det nordlige landskapet knyttes med det sentrale og hjemlige, slik man opplever det i Gaups litterære univers.

Møtet med det eksotiske, snødekte, kalde nord, som er en viktig handlingstråd på det sekundære nivået i Rydde ut, starter som en overfladisk erfaring gjort fra hovedstadens perspektiv: "Gatene er annerledes enn i Oslo, og det tar noen sekunder fra hun registrerer det, til hun forstår hvorfor: Det er ikke 
strødd. Snøen ligger jomfruelig og hvit på fortauene" (Uri, 2013: 65). På en av sine første turer til butikken (med "mindre utvalg enn butikkene hjemme i Oslo", Uri, 2013: 66) treffer Ellinor Kåre, en mann som lukter "frisk svette, havsprutt, vidde og testosteron" (Uri, 2013: 67), og leseren făr plutselig en fornemmelse av å bli dratt inn i en klisjefylt kjærlighetsroman, med NordNorge som kulisser. En del av klisjeen er sjamanismen: i motsetning til Trommereise reduserer denne romanens sekundære nivå sjamanisme til eksotisk ferniss. En nokså ironiserende, men symptomatisk bedømmelse kom fra en VG-anmelder, som ellers hadde sans for det slektsgranskende ved Rydde $u t$ : "men stakkars Ellinor må tåle å leve helt på grensen til underholdningslitteraturens utposter, særlig da hun møter samiske «hekser» og en staut villmarkssønn med erotisk naturtalent” (Lerum, 2013).

En romantisk affære mellom Ellinor og Kåre utvikler seg i pakt med klisjeene om det eksotisk etniske ("En ekte same? Å ja, svarer Ellinor. Så eksotisk, sier venninnen, er han ... fyrig? Har han sånn stjernelue? Eier han mange reinsdyr?" (Uri, 2013: 159)). Jeg-fortelleren lar likevel sin fiktive heltinne modne i møte med det nordlige landskapet. Hun velger nord framfor sør, men på egne premisser, ikke blendet av romantisk kjærlighet som etter sigende skal oppheve etniske grenser: "Jeg har skaffet henne jobb, sikret leilighet. Hun smiler, er på vei mot Oslo. Byen hun har vokst opp i, byen jeg har vokst opp i (...) Men Ellinor nekter. Hun trosser meg. (...) Og jeg blir stående igjen, betrakte baklysene på bilen helt til de forsvinner" (Uri, 2013: 259).

Kjærlighetsmotivet på det sekundære fiksjonsnivået fordobles ved hjelp av en kinesisk-eske-effekt. Gjennom en av sine intervjuobjekter, den lokale "heksen" og sameaktivisten Anna, făr Ellinor vite om en tre generasjoners gammel konflikt mellom to finnmarksslekter. Kilden til de vonde følelsene var ulykkelig kjærlighet som Annas bestemor, Ravna, næret til den svikefulle samegutten Benedikt. Etter å ha gjort Ravna gravid, giftet Benedikt seg over sin stand med den norske enkefrua han hadde arbeidet på gården for. Denne fortellingen er en mulig parallell til Helenes slektshistorie. Man vet lite om omstendighetene rundt hennes samiske oldefars ekteskap med den norske enken Oline. Også hennes farfar hadde på vei oppover samfunnsstigen sviktet kjærligheten og vedkjente seg ikke sitt "uekte" barn.

Kjærlighet på tvers av etniske grenser er en del av den nasjonale metaforikken, og er dermed ikke noe tilfeldig i Rydde ut. Den nasjonsbyggende og nasjonsbekreftende romanen fra 1800-tallet baserer seg på kjønnog familiemetaforikken, påpeker Oxfeldt. Hun viser til Doris Sommer og hennes undersøkelse av kjærlighetsromaner i den latinamerikanske nasjonsbyggende diskursen. I disse romanene, som fokuserer på kjærlighet mellom mann og kvinne, fremtrer hjem og familie som størrelser parallelt med nasjonen. Sommer hevder i sin studie at de nasjonale ideene åpenbarer seg $\mathrm{i}$ "naturlig" heteroseksuell kjærlighet og gjennom ekteskap som blir bilder på en 
tilsynelatende ikke-voldelig konsolidering. I slike romaner forelsker mann og kvinne seg i hverandre på tvers av rase, etnisitet, klasse, regional tilhørighet. Dette skulle - i tråd med den nasjonsbyggende pedagogikken - inspirere forskjellige befolkningsgrupper i en ung nasjon til å slå seg ned under samme tak og lage en grobunn for en felles stat som ikke nødvendigvis skal bygge på likhet mellom forskjellige samfunnsgrupper og -lag.

Romance had, therefore, to give a loving cast to national unity, not necessarily to equalize the lovers. (...) Whether the plots end happily or not, the romances are invariably about desire in young, chaste heroes for equally young and chaste heroines in order to establish conjugal and productive unions which represent national unification and which can be frustrated only by illegitimate social obstacles. Overcoming those obstacles produces the desired end (...), while failure ends in tragedy" (Sommer, 1990: 82).

I Rydde ut får den erotisk-nasjonale retorikken en ambivalent klang. På fiksjonens sekundære nivå fremtrer det samisk-norske ekteskapet heller som et svik og en kynisk fornektelse av sine egne enn som en kilde til framtidshåp. Også på fiksjonens primære nivå knyttes "erotikk-på-tvers-av-etnisitet"-prosessen med antagonisering, benektelse, undertrykking, fortielse og klipping av kunnskapens og tradisjonens bånd. Dette skinner gjennom jeg-personens ord:

Da farfar var gutt og så nordlyset flamme over Sørøya, fortalte faren hans kanskje om flokken med kjempesvaner som fløy lenger og lenger nord. Så langt mot nord fløy de, at de frøs fast $\mathrm{i}$ isen. Hver gang de stakkars svanene forgjeves bakser med vingene for å komme løs, danser nordlyset over himmelen. Historier om onde stalloer og vakre uldaer (...) Men farfar fortalte ikke historiene til noen av sine tre sønner, så pappa kunne ikke fortelle dem videre til meg" (Uri, 2013: 211).

\subsection{EN FORTELLING OM SKYLD OG SKAM?}

"Fornorskningspolitikken har vært brutal. Den norske stat har innrømmet det - og bedt om tilgivelse. Det spørs vel om staten noen gang får den tilgivelsen", tviler Helene (Uri, 2013: 136). I Rydde ut tematiseres skyld-ogskamfølelsen på minst to nivåer. Først og fremst dreier det seg om skammen over å tilhøre minoriteten. "I Wikipedia-artikkelen står det: «Det var lenge knyttet mer skam til å være sjøsame enn til å være innlandssame.» Skammet farfar seg? Er det derfor jeg aldri har hørt noe om en samisk oldefar?" (Uri, 2013: 42).

"Jeg føler det ikke som en del av meg som er tapt, jeg påberoper meg ikke en tilhørighet jeg ikke har" (Ballovara, 2013), hevdet Helene Uri i forbindelse med lansering av Rydde ut. Hun skrev sin roman ut fra et ambivalent perspektiv: Selv om hun selv og hennes autofiktive jeg-person mest sannsynlig vil definere seg som en representant for storsamfunnet, er det samiske en 
unektelig del av livshistorien - både til forfatteren og til hennes jeg-person. Det er selvsagt vanskelig å uttale seg om den virkelig Helene Uri, men i alle fall er hennes jeg-person slett ikke trygg på sitt forhold til det samiske i seg:

Nå om dagen funderer jeg på hva jeg tenkte da jeg oppdaget at farfar var sønn av en sjøsame. De fremste følelsene er ikke vanskelige å huske, identifisere og gjenkjenne: Jeg var overrasket og uforberedt (...) Var jeg skamfull? Jeg har senket meg ned i egne avgrunner, lett med lys og lykt etter skam og vanære, men det har jeg ikke funnet spor av (Uri, 2013: 93).

Den andre dimensjonen av skamfølelsen er av en selvanklagende karakter, og dreier seg om Helenes forhold til det samiske. "Hvis jeg graver dypt ned i forfengeligheten: Er det sånn at jeg hadde syntes at det var mer stas med en greve i slekten enn en same?" (Uri, 2013: 94). Det dreier seg ikke nødvendigvis om en åpenbar ringeakt for samer. Fortellingen fremstår stundom som et indirekte oppgjør med det allmenn-norske eksotiserende og den ufarliggjørende mytifiseringen av den etniske minoriteten. Helene har blant annet et fjernt barndomsminne om ei samelue, en gave fra foreldrenes venner, antar hun. Sameluen er et meget betydningsfullt hodeplagg. Det finnes mange varianter av den, og variantene er kjønns- og stedsbestemt. De forteller om eierens tilhørighet og identitet. Helene tror ikke luen var en gave fra slektningene. Det var rett og slett en suvenir, tatt ut av konteksten. Episoden med sameluen framstår som et tegn på at det samiske i hennes barndomsminner avindividualiseres, infantiliseres og reduseres til todimensjonale tablåer:

Jeg elsket denne luen, og jeg elsket å leke at jeg var en samepike, samepiken Laila, for det var det samepiken het, hvis de da ikke het Ravna. Og på TV gikk serien om samegutten Ante, som alle så, om ikke annet så fordi det bare fantes én norsk kanal. En samisk oldefar hadde passet meg utmerket. En kledelig kontrast. Passelig eksotisk, passelig fjernt (Uri, 2013: 94).

Homi Bhabhas oppskrift på den nye postnasjonale identitet knyttes til forhandlinger mellom de gamle nasjonale elitene og minoriteter i det såkalte tredje rommet, third space. Det tredje rommet kan forstås som en diskursiv praksis som frigjør individer fra rigide identitetsoppfatninger, og som frigjør betydninger og symboler fra deres kulturforankrede primære homogenitet. Det er et liminalt rom, på grensen mellom språkene, kulturene; på grensen mellom "jeg" og "du" (Bhabha, 2010: 23-25). Det er et rom hvor motsetninger føyes sammen, akkurat som i det sjamanistiske bildet av virkeligheten der det håndfaste og synlige får sin mening gjennom sitt usynlige, åndelige motstykke (Szyjewski, 2005: 154). I det tredje rommet åpnes de primært homogene kulturtegnene for re-definering, re-historisering, overtakelse og omtolkning. 
Der kan de enkelte kulturenes hybride natur komme fram. Dette kan i sin tur resultere i en dialog mellom kulturer uten eksotisering, antagonisering eller petrifisering av den kulturelle diversitet; en dialog som vil baseres på at vårt "jeg" forvandles i de andre.

Rydde ut forteller eksplisitt om antagoniseringer, om bevissthetens stengte rom og ikke minst om fortrenging av sitt indre som en form for nødvendige forsvarsmekanismer:

Kunne farfar snakke samisk? Kunne han forstå? Eller ville ikke Ola at Nicolai, som jeg har gjort til kjærlighetsbarnet, skulle lære samisk? Stengte faren den døren, slapp han ikke Nicolai inn i rommet med latter, sagn, gode jakthistorier og joik? Eventyr om onde stalloer, lokkende uldaer med vakre kofter og langt hår, blodtørstige tsjuder. Jeg tror at Ola og Nicolai hadde dette hemmelige rommet som Nicolai ble invitert inn i, og som moren som vestlending ikke hadde adgang til. Et rom som Nicolai selv lukket da han reiste fra Finnmark, giftet seg og slo seg ned på Østlandet, men av og til gløttet han på døren inn dit, hvisket noen ord på samisk inni seg, tenkte på en av farens skrøner - den om den magiske hvite simla - og smilte for seg selv. Hva tenker du på? Spurte Astrid lavt. (...) Ingenting, svarte Nicolai (Uri, 2013: 179).

Rydde ut skaper en parallell mellom slektsgranskning og korrigering av nasjonens selvbiografi. Helenes narrasjon styres av modaliteter ("kanskje", "jeg tror jeg vet", "han må jo ha sittet") og retoriske spørsmål som ikke blir besvart ("Skammet farfar seg?") Hun vil rekonstruere en sammenheng i slektshistorien, men det hun gjør, er å skape en fortelling i spenningsfeltet mellom stolt tale ("Moren min elsket å snakke om slekten sin", s. 60) og skamfull taushet ("Jeg spurte aldri pappa hva slags hus hans far vokste opp i. Pappa må jo ha sittet på sin fars kne og spurt om farfarens barndom (...) Men kanskje svarte ikke faren", s. 42). Det kan sies å være et forsøk på å skape det Bhabhanske tredje rommet i den litterære diskursen; et rom som får næring av impulsutvekslinger mellom motsetninger og som konstitueres av en kontinuerlig forhandling mellom mellom nåtid, framtid og fortid.

\section{AVSLUTNING}

I begge de omtalte romanene assosieres det nordlige landskapet med individets påtvungne (Trommereisen) eller frivillige (Rydde ut) løsrivelse fra det hjemlige, og avkutting av tilhørighetsbånd. Løsrivelsen skjer enten i forbindelse med den påtvungne assimileringspolitikken (sett som en nødvendig fase i den nasjonsbyggende prosessen), eller framstår som et individuelt valg, en form for menneskets tilpassing til de eksisterende samfunnsmessige maktkonstellasjonene. 
Begge romaner tematiserer nødvendigheten av å gjenfortelle individets og nasjonens historie slik at man fanger opp det som på grunn av de historiske og samfunnsmessige omstendigheter har vært presset inn under den offisielle narrasjonen om landet og menneskene som har bygget det. Reisen nordover, den speilvendte eksil-/migrasjonsreisen, foretatt både på det mentale og det fysiske planet, hjelper begge fortellerne å komme nærmere den undertrykte og fragmenterte kunnskapen.

Det som tydelig skiller dem fra hverandre, er fortellerens syn på det etniske i mennesket, noe som gjennom analogi kan antyde synet på nasjonens etniske dimensjon. Trommereisen formidler fortellerens essensialistiske holdning til individets etniske "jeg". Det samiske som Jon må komme i kontakt med for å oppleve seg selv som en helhet, bæres først og fremst av myten (og i tillegg av den tradisjonelle levemåten). I Rydde ut er det etniske ved jegfølelsen en nokså diffus størrelse, vanskelig å fange opp, som slett ikke er avhengig slike åpenbare bestanddeler som mytisk fortid eller tradisjonell levevei. Dette kommer klart til uttrykk på romanens sekundære nivå, der sjamanismen og livet på Finnmarksvidda presenteres som parodiske klisjéer, og der man antyder at kartlegging av den etniske delen av identiteten kan defineres på det enkelte individets premisser.

Begge romanene har i tillegg forskjellige oppfatninger av rekonstrueringsprosessen: Uris roman har et langt mer desillusjonert syn på den. Mens Trommereisen eksplisitt uttrykker et håp om å kunne reelt reetablere den tapte sammenhengen $\mathrm{i}$ individets og folkets historie, viser romanen til Helene Uri det utopiske ved å bringe tilbake det en gang marginaliserte og fortrengte på en annen måte enn i form av en flerstemmig fortelling. En annen form for det Bhabhanske tredje rom enn en dialogisk litterær diskurs gis det lite håp om i Rydde ut.

\section{LITTERATUR}

Andersen, P. T. (2013). “Hvor burde jeg da vare?" Kosmopolitisme og postnasjonalisme i nyere litteratur". Oslo: Universitetsforlaget.

Bhabha, H. K. (1990). DissemiNation: time, narrative, and the margin of the modern nation. I: H. K. Bhabha (red.), Nation and Narration (s. 291-322). London: Routledge.

Bhabha, H. K. (2010). Miejsca kultury Tłum. T. Dobrogoszcz. Kraków: Wydawnictwo Uniwersytetu Jagiellońskiego.

Davidson, P. (2005). The idea of North. London: Reaktion Books.

Drivenes, E.-A.. (et al.). (1994). Nordnorsk kulturhistorie. Bind 1. Oslo: Gyldendal.

Egerer, C. (1997). Fictions of (In)Betweenness. Göteborg: Acta Universitatis Gothoburgensis.

Frank, S. (2008). Migration and literature. Günter Grass, Milan Kundera, Salman Rushdie, and Jan Kjarstad. London: Palgrave Macmillan.

Gaup, A. (1982). Joiken og kniven. Oslo: Gyldendal.

Gaup, A. (1984) I Stallos natt. Oslo: Gyldendal.

Gaup, A. (1986). Under dobbel stjernehimmel. Karasjok: Davvi Media.

Gaup, A. (1988). Trommereisen. Oslo: Gyldendal. 
Gaup, A. (1992). Natten mellom dagene. Oslo: Gyldendal.

Jonsson, E. ( 2016). Sigbjørn Skåden. www.versopolis.com/poet/67/sigbjrn-skden/ (15.05.2017)

Kristeva, J. (1994). Svart sol. Depresjon og melankoli. Overs. A. Øye. Oslo: Pax.

Kristeva, J. (1995). Dissidenten - en ny sort intellektuell. Övers. A. Runnqvist-Vinde. I: J. Kristeva, Stabat Mater och andra texter (s. 64-72). Stockholm: Natur och Kultur.

Lerum, M. G. (2013). En forfatter krysser sine familiespor.VG 26.08.2013. https://www.vg.no/ rampelys/bok/bokanmeldelse/bokanmeldelse-helene-uri-rydde-ut/a/10133123/ (15.05.2017)

Nergård, J. I. (1994). Det skjulte Nord-Norge. Oslo: Ad Notam Gyldendal.

Oxfeldt, E. (2012). Romanen, nasjonen og verden. Oslo: Universitetsforlaget.

Rottem, Ø. (1990). Ailo Gaup: Trommereisen. I: Ø. Rottem (red.), Fantasiens tiår. Tekstens illusjoner og desillusjonens tekster. Et utvalg litteraturkritikk 1980-89 (s. 417-419). Oslo: Aschehoug.

Said, E. W. (1984). The Mind of Winter. Reflections on life in exile. Harper's magazine, nr 269, 49-55

Schimanski, J. (et al.). (2011). Arktis som et litterært prosjekt. I: J. Schimanski et al. (red.), Reiser og ekspedisjoner (s. 9-28). Trondheim: Tapir Akademisk Forlag

Sibińska, M. (2000). Landskapets mytiske dimensjon i Under dobbel stjernehimmel og Trommereisen. I: M. Marnersdóttir, J. Cramer (red.), Nordisk litteratur og mentalitet (s. 476-484). Tórshavn: Føroya Fróðskaparfelag.

Sibińska, M. (2002). Marginalitet og myte i modern nordnorsk lyrikk. Gdańsk: Wydawnictwo Uniwersytetu Gdańskiego.

Sommer, D. (1990). Irresistible romance. The foundational fictions of Latin America. I: H. K. Bhabha (red.), Nation and Narration (s. 71-98). London: Routledge.

Szyjewski, A. (2005). Szamanizm. Kraków: WAM.

Uri, H. (2013). Rydde ut. Oslo: Gyldendal.

Østtveit, K. (2009). Skammen ut av skapet. Aftenposten, 23.1.2009. https://www.aftenposten.no/ amagasinet/i/R9Je2/Skammen-ut-av-skapet (15.05.2017).

\section{Maria Sibińska}

Uniwersytet Gdański

Wita Stwosza 51

80-308 Gdańsk

Poland

films@univ.gda.pl 